\title{
Interspecific variability of endocrine disruption and oxidative stress in two bivalve species from the Ria Formosa Lagoon (south coast of Portugal)
}

\author{
CATARINA PEREIRA, TÂNIA GOMES, CÁTIA CARDOSO, ANA CATARINA \\ ALMEIDA, OLINDA ARAÚJO, MARIA JOÃO BEBIANNO and ALEXANDRA CRAVO \\ CIMA, Faculty of Sciences and Technology, University of Algarve, Campus de Gambelas, 8005-139 Faro, Portugal. \\ E-mail: acravo@ualg.pt
}

\begin{abstract}
SUMMARY: Estuaries are highly productive ecosystems that have been increasingly affected by anthropogenic activities. In this study, the presence of endocrine disrupting compounds (EDCs) and their relation to oxidative stress were assessed in two bivalve species (mussels Mytilus galloprovincialis and clams Ruditapes decussatus) from the Ria Formosa Lagoon (south Portugal). We applied the alkali-labile phosphate (ALP) assay to determine vitellogenin-like protein levels, and the lipid peroxidation (LPO) method to assess oxidative damage. Mussels and clams exhibited the same pattern of ALP concentrations, with no differences between genders and higher levels in winter. R. decussatus showed higher ALP values than M. galloprovincialis, possibly associated with a stronger responsiveness of clams to EDCs or due to the influence of the reproductive cycle. Mussels exhibited a more evident seasonal effect for LPO, indicating that these organisms are more influenced by seasonal fluctuations in the water column compared to the sediment-associated clams. Both species appear to be under the influence of EDC exposure (which could induce Vg-like protein synthesis) and oxidative stressors (leading to lipid peroxidation) in the Ria Formosa Lagoon, particularly in winter, reflecting the presence of different contaminants in Ria Formosa and environmental changes, as well as complex interactions between them.
\end{abstract}

Keywords: Ria Formosa Lagoon, Mytilus galloprovincialis, Ruditapes decussatus, endocrine disruption, vitellogenin-like proteins, lipid peroxidation.

RESUMEN: VARIABILIDAD INTERESPECÍFICA DE DISRUPTORES ENDOCRINOS Y ESTRÉS OXIDATIVO EN DOS ESPECIES DE BIVALVOS DE LA Ría Formosa (COSTA SUR DE PORTUGAL). - Los estuarios son ecosistemas altamente productivos afectados por actividades antropogénicas. En este trabajo, la presencia de compuestos disruptores endocrinos (EDCs) y su relación con estrés oxidativo se ha evaluado en los bivalvos Mytilus galloprovincialis y Ruditapes decussatus en la laguna Ría Formosa (Portugal). Se utilizó el ensayo de fosfatos lábil alcalinos (ALP) para determinar los niveles de proteína tipo-vitelogenina y el método de peroxidación lipídica (LPO) para evaluar los daños oxidativos. Ambas especies exhibieron el mismo patrón de concentración de ALP: no hubo diferencias entre sexos pero si niveles más altos en invierno. R. decussatus presentó valores mayores de ALP que $M$. galloprovincialis posiblemente asociados a una capacidad de respuesta más elevada a los EDCs o al estado del ciclo reproductor. Los mejillones, al no estar asociados al sedimento como las almejas, mostraron variaciones estacionales en las concentraciones de LPO, indicando mayor sensibilidad a fluctuaciones ambientales en la columna de agua. Ambas especies parecen estar influenciadas (principalmente en invierno) por EDCs (posiblemente induciendo la síntesis de proteína tipo-vitelogenina) y factores de estrés oxidativo (activando la peroxidación lipídica); lo que refleja la presencia de diferentes contaminantes en la Ría Formosa y los cambios ambientales, así como las complejas interacciones entre ellos.

Palabras clave: Ría Formosa, Mytilus galloprovincialis, Ruditapes decussatus, disrupción endocrina, proteínas tipovitelogenina, peroxidación lipídica.

\section{INTRODUCTION}

Estuaries are usually highly productive ecosystems that over the years have become increasingly affected by anthropogenic activities, mainly due to urban development, industrialization and tourism (Cravo et al. 2009). In these areas, complex mixtures of contaminants are released from municipal and industrial efflu- 
ents, and also agricultural and urban runoff (Gagné et al. 2001a). Discharged substances include a wide array of compounds like metals, polyaromatic hydrocarbons, fertilizers, pesticides, pharmaceutical and personal care products (PPCPs), among others, that are capable of inducing deleterious effects in exposed organisms (Gagné et al. 2001a, Cravo et al. 2009).

Many of these contaminants possess the ability to disturb normal reproductive functions by disrupting the endocrine system. These chemicals, named "endocrine disrupting compounds" (EDCs), represent a structurally diverse group that includes both natural and synthetic steroid estrogens, as well as a variety of estrogen-mimicking chemicals (or xenoestrogens) such as surfactants (like nonylphenol and octylphenol), plasticizers (like bisphenol-A), polychlorinated biphenyls and organochlorine pesticides (Matozzo et al. 2008, Gagnaire et al. 2009). EDCs interfere with the activity of endogenous hormones by mimicking the action of natural hormones, acting as oestrogen agonists, or altering the pattern of synthesis and metabolism of hormones and eliciting a biological response (Quinn et al. 2004, Matozzo et al. 2008). The reproductive function can be affected by these compounds particularly through the induction of vitellogenins ( $\mathrm{Vg}$ ), precursors of the egg yolk proteins, and vitellins (Vn), which provide energy to support embryonic development in oviparous organisms (Matozzo et al. 2008, Gagnaire et al. 2009). Vg are high density glycolipophosphoproteins considered to have similar characteristics in vertebrates, such as fish, and invertebrates, particularly molluscs (Blaise et al. 1999, Matozzo et al. 2008). In mature female vertebrates, $\mathrm{Vg}$ is synthesized in extraovarian tissues (such as the liver) in response to endogenous estrogens released into the bloodstream and stored in developing oocytes (Gagnaire et al. 2009). In molluscs, gonads are reported to be the source of $\mathrm{Vg}$ like proteins, and synthesis occurs either within the oocytes or the surrounding connective tissue (Marin and Matozzo 2004). Vg levels generally increase in sexually mature females, but are low in juveniles and almost undetectable in males (Matozzo et al. 2008). However, natural estrogens and xenoestrogens may induce vitellogenesis, an effect particularly striking in males or juveniles that has been extensively used as a biomarker of endocrine disruption in fish (Porte et al. 2006) and more recently in bivalves (Blaise et al. 1999, Gagné et al. 2001a, Matozzo et al. 2008). In the latter case, increased levels of Vg-like proteins have been reported in gonads and haemolymph of both male and female mussels (Gagné et al. 2001a,b, Quinn et al. 2004) and clams (Blaise et al. 1999, Gagné et al. 2002, Matozzo and Marin 2005) exposed in laboratory and field studies to hormones like estradiol, compounds such as nonylphenol, municipal effluents and urban and agricultural runoff waters. Consequently, these proteins can be useful biomarkers in assessing the potential exposure and estrogenic effects in bivalves.
Several methodologies have been developed to assess Vg levels in fish as well as in bivalves. Direct assays based on the use of specific antibodies (enzymelinked immunosorbent assay -ELISA, radio-immunoassays - RIA, Western blot analysis) or molecular tools (DNA hybridization; protein expression studies) are generally recognised as more specific and sensitive methods (Marin and Matozzo 2004, Porte et al. 2006). However, they are expensive, time-consuming and require a high level of expertise and technology. Moreover, only a few specific antibodies are developed against bivalve $\mathrm{Vg}$ and these usually show low crossreactivity across species (Blaise et al. 1999, Marin and Matozzo 2004, Porte et al. 2006, Gagnaire et al. 2009). Therefore, alternative indirect methods that are significantly correlated with direct assays have been developed, such as the alkali-labile phosphate (ALP) assay (Gagné and Blaise 1998, Blaise et al. 1999, Gagné et al. 2003, Matozzo et al. 2008, Gagnaire et al. 2009). The ALP assay is based on determining labile phosphates released by these lipophosphoproteins after hydrolysis with alkalis, thus the Vg protein levels are assessed indirectly (Blaise et al. 1999, Gagné et al. 2001a,b, 2003, Matozzo and Marin 2005). Consequently, this release of inorganic phosphates by the $\mathrm{Vg}$-like proteins can be considered a biomarker response to EDCs, not limited to one species and representing a rapid and cost-effective alternative to direct methods (Gagné et al. 2002, Marin and Matozzo 2004, Matozzo and Marin 2005, Gagnaire et al. 2009).

Exposure to contaminants may also induce or inhibit antioxidant systems in a living organism, which may lead to oxidant-mediated toxicities such as the production of reactive oxygen species (ROS). Antioxidant defence systems neutralize chemical reactive compounds produced by endogenous pathways and/or xenobiotic metabolism (Cossu et al. 2000, Viarengo et al. 2007). When activated, defences can be insufficient to counteract ROS production and protect tissues from oxidative damage. This oxidative stress may produce peroxidation of cell constituents, especially lipid peroxidation (LPO) (Blaise et al. 2002, Viarengo et al. 2007). This effect is associated with oxidative disruption in the lipid components of cellular membranes, resulting in products of lipid degradation and free radicals, all extremely toxic for the cell (Bebianno et al. 2004, Viarengo et al. 2007). Given the complex mixture of contaminants present in aquatic ecosystems, LPO constitutes a useful biomarker of damage since it reflects not only exposure to pollutants but also toxicity, and its response is nonspecific to any kind of contaminant (Cossu et al. 2000; Viarengo et al. 2007).

To assess endocrine disruption and oxidative effects caused by contaminants in aquatic environments, it is necessary to define suitable indicator organisms affected by multiple contamination agents. In environmental studies, bivalve molluscs such as mussels and clams have been widely used as bioindicators in 
biomonitoring and quality assessment programs. These ubiquitous and sessile organisms accumulate contaminants to a great extent and respond significantly to pollutant exposure (Bebianno et al. 2004, Barreira et al. 2007). Mussels are sedentary filter-feeders that feed from the surrounding water (Bocchetti et al. 2008) whereas clams are endobenthic suspension feeders that have the potential to accumulate bioavailable contaminants from both water and sediments (Blaise $e t$ al. 2002). The use of mussels Mytilus galloprovincialis and clams Ruditapes decussatus as bioindicators is widespread since they are widely distributed and common in the Mediterranean (Bebianno et al. 2004). Both species are ecologically and commercially important and clams in particular have a relevant economic impact due to their enhanced production and harvesting for human consumption in Portugal.

This study aimed to evaluate the presence of endocrine disruption compounds and their relation to oxidative stress in the Ria Formosa Lagoon (south Portugal) by assessing the interspecific variability response of two important bivalve species (mussels Mytilus galloprovincialis and clams Ruditapes decussatus). Thus, the ALP assay was applied to determine the Vg-like protein levels and the LPO method to assess oxidative damage. To our knowledge, this is the first study reporting ALP concentrations in gonads of the species $M$. galloprovincialis and $R$. decussatus.

\section{MATERIALS AND METHODS}

\section{Study area}

The study area was located in the Ria Formosa Lagoon, on the south coast of Portugal, near the urban centre of Olhão (Fig. 1). The Ria Formosa is a shallow, highly productive mesotidal lagoon sys-

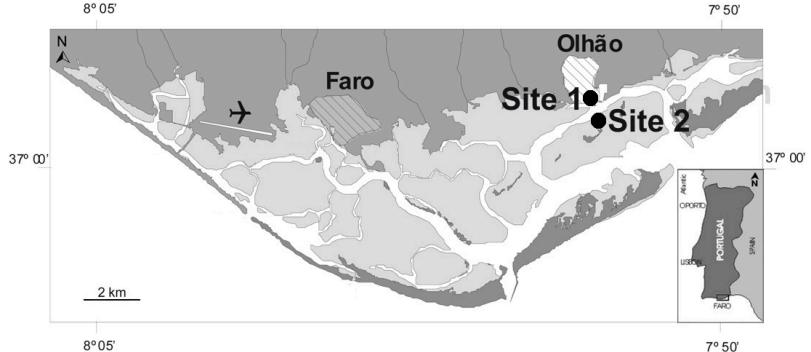

FIg. 1. - Study area in the Ria Formosa Lagoon, south coast of Portugal, and sampling locations near the urban centre of Olhão. Barrier islands are in light grey. Site 1: fishing harbour pier where mussels Mytilus galloprovincialis were collected. Site 2: shellfish bed where clams Ruditapes decussatus were sampled.

tem with a length of about $55 \mathrm{~km}$ and a maximum width of $6 \mathrm{~km}$ (Bebianno 1995). Designated in 1987 as a National Park and recognized as an important wetland at both the European and international levels (Natura 2000 and Ramsar Convention), the Ria Formosa is a valuable regional resource for tourism, salt extraction, fisheries and aquaculture, with a long tradition in bivalve harvesting (e.g. Ruditapes decussatus, Mytilus galloprovincialis). All of these activities depend on good water quality (Bebianno 1995, Bebianno et al. 2004). A seaward belt of dunes protects a system of salt marshes, subtidal channels and tidal flats that interact with the surrounding oceanic waters via several inlets. Its western boundary area is heavily urbanized and surrounded by agricultural land (Ribeiro et al. 2008). The lagoon does not receive any significant freshwater inputs, and the main contributions come from the Gilão River, domestic sewage, industrial effluents and agriculture runoffs. Consequently, the water quality in the lagoon is deteriorating, and thus the natural resources are declining (Bebianno 1995).

TABLE 1 - Contaminants and concentrations determined in different compartments (bivalve tissues, water and sediments) of areas close to the city of Olhão, in the Ria Formosa Lagoon.

\begin{tabular}{|c|c|c|c|c|}
\hline Contaminant & Concentrations & Compartment & Site & Author \\
\hline $\begin{array}{l}\mathrm{Cd} \\
\mathrm{Cu} \\
\mathrm{Cr} \\
\mathrm{Ni} \\
\mathrm{Pb} \\
\mathrm{Zn}\end{array}$ & $\begin{array}{l}0.5 \pm 0.1 \mu \mathrm{g} \mathrm{g}^{-1} \mathrm{dw} \\
10 \pm 2.8 \mu \mathrm{g} \mathrm{g}^{-1} \mathrm{dw} \\
0.4 \pm 0.0 \mu \mathrm{g} \mathrm{g}^{-1} \mathrm{dw} \\
0.1 \pm 0.01 \mu \mathrm{g} \mathrm{g}^{-1} \mathrm{dw} \\
5.6 \pm 3.2 \mu \mathrm{g} \mathrm{g}^{-1} \mathrm{dw} \\
111 \pm 16 \mu \mathrm{g} \mathrm{g}^{-1} \mathrm{dw}\end{array}$ & $\begin{array}{l}\text { M. galloprovincialis } \\
\text { (whole tissue) }\end{array}$ & fishing harbour & Cravo et al. 2009 \\
\hline $\begin{array}{l}\mathrm{Cd} \\
\mathrm{Cu} \\
\mathrm{Zn}\end{array}$ & $\begin{array}{c}13.6 \pm 4.8 \mathrm{nmol} \mathrm{g}^{-1} \mathrm{dw} \text { (gills) } \\
22.7 \pm 7.6 \mathrm{nmol} \mathrm{g}^{-1} \mathrm{dw} \text { (dig. gland) } \\
155.7 \pm 35.6 \mathrm{nmol} \mathrm{g}^{-1} \mathrm{dw} \text { (gills) } \\
171.7 \pm 32.8 \mathrm{nmol} \mathrm{g}^{-1} \mathrm{dw} \text { (dig. gland) } \\
1534 \pm 188 \mathrm{nmol} \mathrm{g}^{-1} \mathrm{dw} \text { (gills) } \\
1372 \pm 100 \mathrm{nmol} \mathrm{g}^{-1} \mathrm{dw} \text { (dig. gland) }\end{array}$ & Ruditapes decussatus & shellfish bed & Bebianno and Serafim 2003 \\
\hline $\begin{array}{l}t \text { PAH } \\
t \text { PAH } \\
t \text { PAH } \\
\text { TBT } \\
\text { TBT } \\
\text { TBT } \\
\text { TBT } \\
t \text { PCB }\end{array}$ & $\begin{array}{l}911 \pm 19.5 \mathrm{ng} \mathrm{g}^{-1} \mathrm{dw} \text { (whole tissue) } \\
\approx 75-300 \mathrm{ng} \mathrm{g}^{-1} \mathrm{ww} \text { (whole tissue) } \\
174 \pm 14 \mathrm{ng} \mathrm{g}^{-1} \mathrm{Ww} \text { (whole tissue) } \\
\approx 0.2-0.3 \mu \mathrm{g} \mathrm{g}^{-1} \mathrm{dw} \text { (whole tissue) } \\
\begin{aligned} \max 33.8 \mathrm{ng} \mathrm{L} \mathrm{L}^{-1} ; \text { mean } 13.7 \mathrm{ng} \mathrm{L}^{-1} \\
\approx 22 \mathrm{ng} \mathrm{L}^{-1} \\
\approx 0.01 \mu \mathrm{g} \mathrm{g}^{-1} \mathrm{dw} \\
\approx 1 \mathrm{ng} \mathrm{g}^{-1} \mathrm{dw} \\
\approx 5 \mathrm{ng} \mathrm{g}^{-1} \mathrm{dw}\end{aligned}\end{array}$ & $\begin{array}{c}\text { M. galloprovincialis } \\
\text { Ruditapes decussatus } \\
\text { Ruditapes decussatus } \\
\text { Ruditapes decussatus } \\
\text { water } \\
\text { water } \\
\text { sediments } \\
\text { sediments } \\
\text { suspended matter }\end{array}$ & $\begin{array}{l}\text { fishing harbour } \\
\text { shellfish bed } \\
\text { shellfish bed } \\
\text { shellfish bed } \\
\text { fishing harbour } \\
\text { coastal area } \\
\text { fishing harbour } \\
\text { tidal flat }\end{array}$ & $\begin{array}{l}\text { Cravo et al. } 2009 \\
\text { Barreira et al. } 2007 \\
\text { Bebianno and Barreira } 2009 \\
\text { Coelho et al. } 2002 \\
\text { Coelho et al. } 2002 \\
\text { Díez et al. } 2005 \\
\text { Coelho et al. } 2002 \\
\text { Barreira et al. } 2005\end{array}$ \\
\hline
\end{tabular}


The present study was undertaken in the middle part of the lagoon, in an area close to the city of Olhão and connected to the open sea by an intricate network of channels. This area is near one of the major fishing harbours on the south coast of Portugal, which is known to have different levels of contamination due to different hydrodynamic and/or exposure conditions, harbour capacity and proximity to the major urban area of Olhão (Maria et al. 2009). Table 1 shows the contaminants already determined by other authors in the study area of the lagoon in three different compartments (sediments, water and bivalves).

\section{Sample collection}

Sampling was carried out in two different seasons, summer (2007) and winter (2008), because anthropogenic pressure increases during the summer due to tourism compared to winter. Mussels Mytilus galloprovincialis were collected on the pier of the fishing harbour $\left(37^{\circ} 01.367^{\prime} \mathrm{N} ; 7^{\circ} 50.212^{\prime} \mathrm{W}\right)$ and clams $R u$ ditapes decussatus were sampled in the neighbouring shellfish bed, located in front of the pier $\left(37^{\circ} 01.000^{\prime} \mathrm{N}\right.$; $7^{\circ} 50.230$ 'W) (Fig. 1).

Abiotic parameters such as water temperature $\left({ }^{\circ} \mathrm{C}\right)$, salinity, $\mathrm{pH}$ and oxygen saturation (\%) were measured in situ at each site with a multiparametric probe (YSI $6600)$. Mussels $(5-7 \mathrm{~cm})$ and clams $(2-4 \mathrm{~cm})$ were collected at low tide and transported alive in cold containers to the laboratory. Tissues were separated and stored according to the intended analysis. The whole soft tissues were used to assess the physiological state of the organisms (condition index). Gonads were separated to determine the vitellogenin-like proteins (ALP assay), and gills to estimate oxidative stress (determined by lipid peroxidation). These tissues were frozen in liquid nitrogen and stored at $-80^{\circ} \mathrm{C}$. Gonads were also fixed in Bouin's solution (acetic acid, formaldehyde and picric acid) and stored in $70 \%$ ethanol for later histological analyses.

\section{Condition Index (CI)}

To assess the physiological state of the organisms the soft tissues and shells of fifteen to twenty individuals of each species were weighted and the condition index $(\mathrm{CI})$ was estimated as a percentage of the ratio between the dry weight of the soft tissues $(\mathrm{g})$ and the dry weight of the shell (g) (Moschino and Marin 2006). Dry weight of soft tissues and shells were obtained at $80^{\circ} \mathrm{C}$, during a maximum period of 24 hours, until reaching constant weight.

\section{Biochemical analysis}

\section{Vitellogenin-like proteins}

The levels of vitellogenin-like proteins were determined by an indirect alkali-labile phosphate method
(ALP), according to Gagné and Blaise (1998), Blaise et al. (1999) and Gagné et al. (2003) that has been shown to be highly correlated with other direct assays (Gagné and Blaise 1998, Blaise et al. 1999). This procedure measures the levels of alkali-labile phosphates that acetone-extracted lipophosphoproteins release when subjected to an alkali treatment (Gagné and Blaise 1998, Blaise et al. 1999, 2002, Gagné et al. 2001a,b, 2003). The levels of inorganic phosphates were determined using the phosphomolybdenum method (Stanton 1968, Gagné and Blaise 1998, Blaise et al. 1999).

Sex differentiation of mussels was determined by microscopic observation (Axiovert S100, Zeiss, at 100x magnification) using a gonadal smear on glass slides. Gonad tissues of 15 mussels and 15 clams (separated by gender) were thawed on ice and homogenized in $25 \mathrm{mM}$ Hepes- $\mathrm{NaOH}$, pH 7.4, containing $125 \mathrm{mM} \mathrm{NaCl}, 1 \mathrm{mM}$ dithiothreitol and $1 \mathrm{mM}$ EDTA at $4^{\circ} \mathrm{C}$. The homogenate was centrifuged at $12000 \mathrm{~g}$ for 30 minutes at $2^{\circ} \mathrm{C}$ and the supernatant (cytosolic fraction) was carefully removed from the pellet and kept on ice before analysis. A subsample of the supernatant was adjusted to $35 \%$ acetone and centrifuged at $10000 \mathrm{~g}$ for 5 minutes. The pellet was dissolved in $1 \mathrm{M} \mathrm{NaOH}$ (for mussels) or $1 \mathrm{mM} \mathrm{NaOH}$ (for clams) at $60^{\circ} \mathrm{C}$ for $30 \mathrm{~min}$. Using a standard curve of known concentrations of inorganic phosphate $\left(\mathrm{KH}_{2} \mathrm{PO}_{4}\right)$, the levels of inorganic phosphates in the gonads were determined using the phosphomolybdenum method. A subsample was mixed with trichloroacetic acid, ultrapure water, molybdenum reagent and Fiske-Subbarow reducer, and the absorbances were measured at $660 \mathrm{~nm}$. Total ALP concentrations were normalized with the total protein content of the gonad, as determined below, and the results were expressed as micrograms of phosphate per milligram of total protein concentration ( $\mu \mathrm{g} \mathrm{PO}_{4} \mathrm{mg}^{-1}$ Prot).

\section{Lipid peroxidation}

The LPO levels were determined following the method described by Erdelmeier et al. (1998), which measures the malondialdehyde (MDA) and 4-hydroxyalkenals (4-HNE) concentrations upon the decomposition by polyunsaturated fatty acid peroxides.

Concentrations were normalized with the total protein content of the gills, as determined below, and the results were expressed as micromoles of MDA and 4-HNE per gram of total protein concentration $(\mu \mathrm{mol}$ $\mathrm{g}^{-1}$ Prot).

\section{Total proteins}

Total protein concentrations were determined in the cytosolic fraction of the gonad tissue according to Bradford (1976) and of the gills according to Lowry (Lowry et al. 1951). Bovine Serum Albumin (BSA) was used as a reference standard material for both methods. 
TABLE 2. - Abiotic parameters (temperature, salinity, $\mathrm{pH}$ and oxygen) measured in situ at each site where mussels and clams were collected in both seasons.

\begin{tabular}{llccc}
\hline Site & Season & Temperature $\left({ }^{\circ} \mathrm{C}\right)$ & Salinity & Oxygen $(\%)$ \\
\hline Fishing harbour pier & Summer 2007 & 22.5 & 36.7 & 8.1 \\
$($ M. galloprovincialis) & Winter 2008 & 18.0 & 33.8 & 8.0 \\
Shellfish bed & Summer 2007 & 25.5 & 35.9 & 84 \\
$($ R. decussatus $)$ & Winter 2008 & 19.4 & 35.6 & 8.0 \\
\hline
\end{tabular}

\section{Gonad histological analysis}

After fixation, gonad tissues of 10 mussels and 10 clams were dehydrated through a graded ethanol series and embedded in paraffin. Histological sections ( $5 \mu \mathrm{m}$ thick) were cut and mounted on coated slides, deparaffinized and re-hydrated, and finally stained with haematoxylin and eosin. Gonad sections were examined microscopically (Axiovert S100, Zeiss, at 100x magnification) to determine the stages of gonadal development and histological alterations. Developmental stages were distinguished according to Villalba (1995): stage 0, resting gonad; stage I, multiplication of the gonia; stage II, progression of gametogenesis; stage IIIA, ripe/mature gonad; stage IIIB, spawning gonad; and post-spawning stages IIIC (restoring) and IIID (reabsorbing).

\section{Statistical analysis}

Data were tested for normality and homogeneity of variances. One-way Analysis of Variance (ANOVA) or Kruskal-Wallis tests were used to determine differences in the parameters (CI, ALP and LPO) in relation to gender, species and sampling season. Tukey's or Dunn's pair-wise multiple comparison tests were applied accordingly. Principal Component Analysis (PCA) was used to assess the influence of different parameters in the overall results. To analyse significant correlations between variables the Pearson correlation was applied. Statistical analyses were performed using SigmaPlot ${ }^{\circledR} 10$ and XLStat 2010. A minimum significance level of 0.05 was used for all statistical analyses.

\section{RESULTS}

The environmental factors (temperature, salinity, $\mathrm{pH}$ and oxygen) measured in each specific sampling spot in both summer and winter are shown in Table 2. Temperature, as expected, was higher in summer $\left(22.5-25.5^{\circ} \mathrm{C}\right)$ than in winter $\left(18.0-19.4^{\circ} \mathrm{C}\right)$, and slightly higher at the clam shellfish bed site. Salinity ranged from 33.8 to 36.7 in both seasons with higher values in summer, and a smaller variation between summer and winter in the shellfish bed area (35.6-35.9). The $\mathrm{pH}$ values were almost constant in both seasons and sampling sites (8.0-8.1). Dissolved oxygen values showed a high variation between sampling sites, with extremely low values at the shellfish bed site in both seasons $(<70 \%)$.

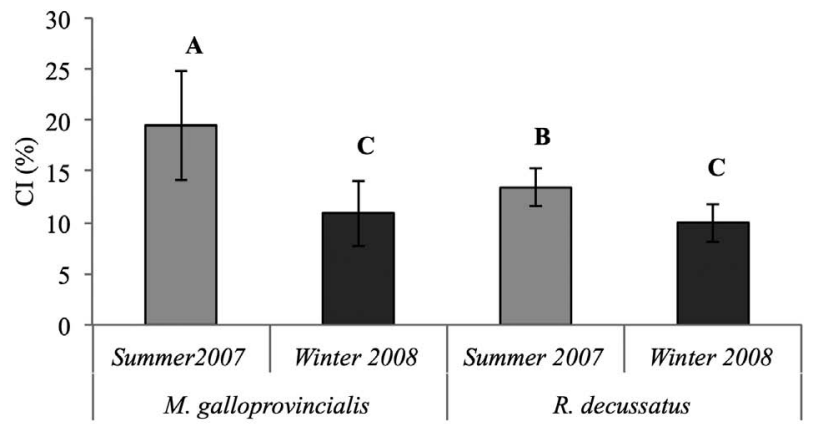

FIG. 2. - Condition Index of M. galloprovincialis and R. decussatus collected in the sampling locations in both summer and winter. The different letters represent significant differences between seasons and species $(p<0.05$, Tukey or Dunn's post-hoc tests).

The condition index of $M$. galloprovincialis and $R$. decussatus is shown in Figure 2. In both species CI was significantly higher in summer $(p<0.05)$ with the maximum for mussels $(19.5 \pm 5.3 \%)$. In winter, the two species showed similar, lower values.
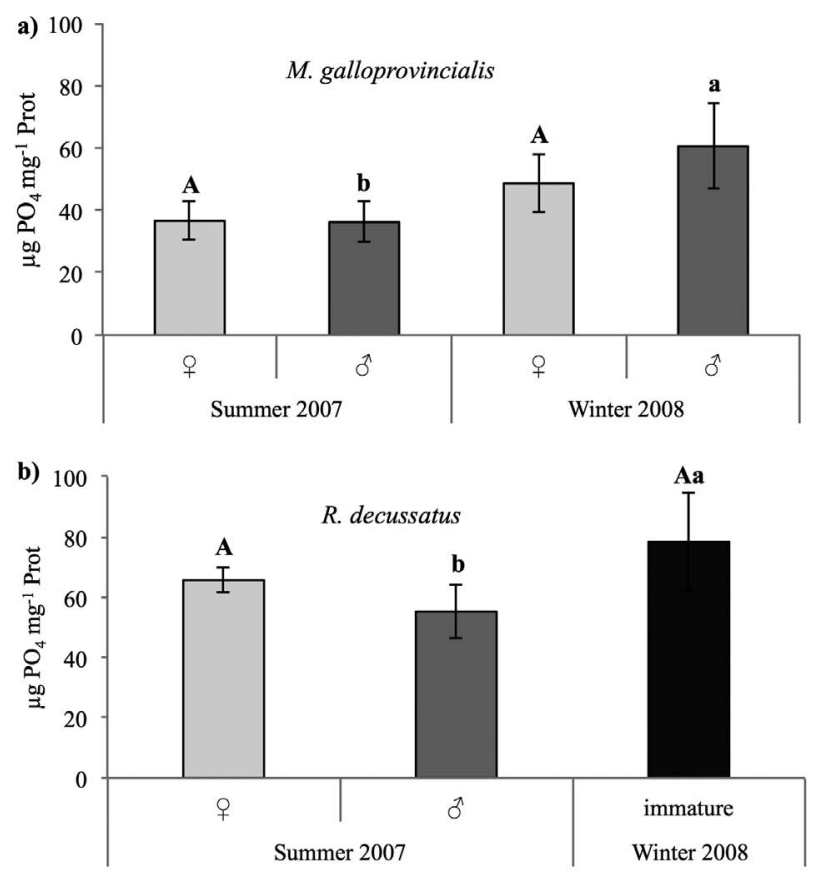

FIG. 3. - ALP concentrations determined in the gonad tissues of females () and males ( $\left.0^{\top}\right)$ a) $M$. galloprovincialis and b) $R$. decussatus collected in the sampling locations in both summer and winter. The different capital letters represent significant differences between seasons for females and the lower case letters for males $(p<0.05$ Tukey or Dunn's post-hoc tests). 


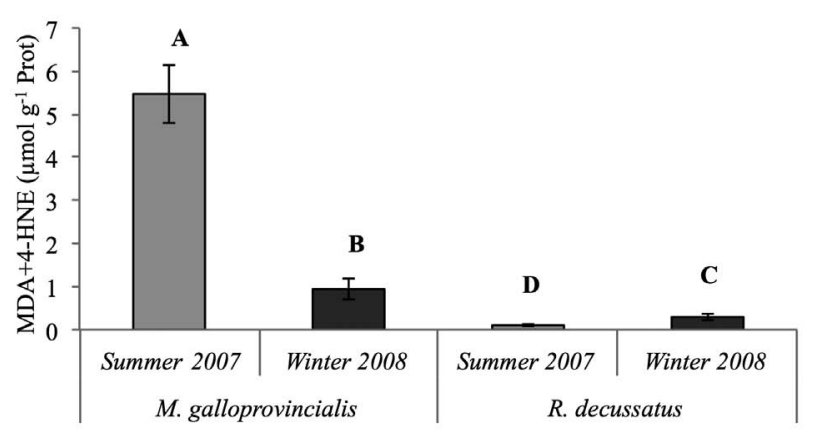

FIG. 4. - LPO concentrations measured in the gill tissues of $M$. galloprovincialis and $R$. decussatus collected in the sampling locations in both summer and winter. The different letters represent significant differences between seasons and species $(p<0.05$, Tukey or Dunn's post-hoc tests).

The analysed biomarkers (Vg-like protein and LPO) in both bivalve species collected in Olhão in summer and winter are shown in Figures 3 and 4.

For M. galloprovincialis, the ALP concentrations did not vary significantly between females and males in either summer or winter $(p>0.05)$. Females showed similar ALP values between seasons (summer $36.7 \pm 6.1$ and winter $48.7 \pm 9.4 \mu \mathrm{g} \mathrm{PO}_{4} \mathrm{mg}^{-1}$ Prot) but males showed significantly higher levels in the winter $\left(60.6 \pm 13.9 \mu \mathrm{g} \mathrm{PO}_{4} \mathrm{mg}^{-1}\right.$ Prot, $\left.p<0.05\right)$. In the summer, females and males had gonads in the same stage of gonadal development (post-spawning stages IIIC and IIID), whereas in the winter, mussels showed a slight sexual asynchrony with males still in the spawning stage (IIIB) and females in more advanced gametogenic post-spawning stages (IIIC and IIID). In terms of histological alterations, only one organism was found infected with a parasite Steinhausia mytilovum in its oocytes. Lipid peroxidation in the gills of mussels was significantly higher in summer $\left(5.5 \pm 0.7 \mu \mathrm{mol} \mathrm{g}{ }^{-1}\right.$ Prot $)$ than in winter $\left(0.9 \pm 0.2 \mu \mathrm{mol} \mathrm{g} \mathrm{g}^{-1}\right.$ Prot, $\left.p<0.05\right)$, which is the opposite of what was observed for the ALP concentrations, particularly in males.

Clams Ruditapes decussatus exhibited no significant differences in the ALP concentrations between genders in the summer $(p>0.05)$. In winter, the clams' gonads were not developed and consequently it was not possible to differentiate genders. However, the organisms collected in this season showed the highest ALP values $\left(78.4 \pm 16.2 \mu \mathrm{g} \mathrm{PO}_{4} \mathrm{mg}^{-1}\right.$ Prot), although these values were only significantly higher than the levels measured in male clams collected in the summer $(p<0.05)$. Both female and male clams from the summer survey had gonads in the ripe/mature (IIIA) and spawning (IIIB) gametogenic stages, while in the winter only immature individuals were found (stage 0 - resting). No histological alterations were detected in the examined organisms. The LPO values in clams were significantly higher in winter $(0.3 \pm 0.0$ $\mu \mathrm{mol} \mathrm{g}{ }^{-1}$ Prot $)$ than in summer $\left(0.1 \pm 0.0 \mu \mathrm{mol} \mathrm{g}{ }^{-1}\right.$ Prot, $p<0.05$ ), a similar trend to that observed for the ALP concentrations.
Both species responded with similar ALP concentration patterns: there were no significant differences $(p>0.05)$ in the ALP values between genders, and higher levels were measured in organisms collected in winter. However, in both seasons clams $R$. decussatus had higher ALP concentrations than mussels M. galloprovincialis; this difference was always significant except for male mussels in the winter survey $(p>0.05)$. Immature clams showed the highest levels determined for both species $\left(78.4 \pm 16.2 \mu \mathrm{g} \mathrm{PO}_{4} \mathrm{mg}^{-1}\right.$ Prot). In terms of gonadal development, in the summer, mussels were in post-spawning stages whereas clams were still ripe and spawning. In the winter, mussels ranged from spawning to post-spawning stages, while all clams were in the resting stage (immature). The LPO trends were the opposite in the two species since mussels showed higher levels in summer (in opposition to that observed for the ALP) and clams in the winter (similar pattern to the ALP). Moreover, M. galloprovincialis exhibited significantly higher LPO concentrations than $R$. decussatus in both seasons $(p<0.05)$.

Correlations were tested to verify the relationships between variables (ALP, LPO and condition index) for both mussels and clams. Only one significant negative correlation was found $(r=-0.997, p<0.05)$ : between the ALP concentrations in males and the condition index. This indicates that when the organism's physiological status was lower, the biomarker for endocrine disruption was higher.

A Principal Component Analysis (PCA) was also applied to all data to assess the influence of the different parameters in the overall results (Fig. 5). There is a clear distinction between species. PC1 explains almost 90\% of the variance and shows that clams (especially in winter) are mainly associated with higher ALP concentrations and show the opposite behaviour to that observed for mussels in summer, which are associated with lower ALP levels but higher LPO and Condition Index values.

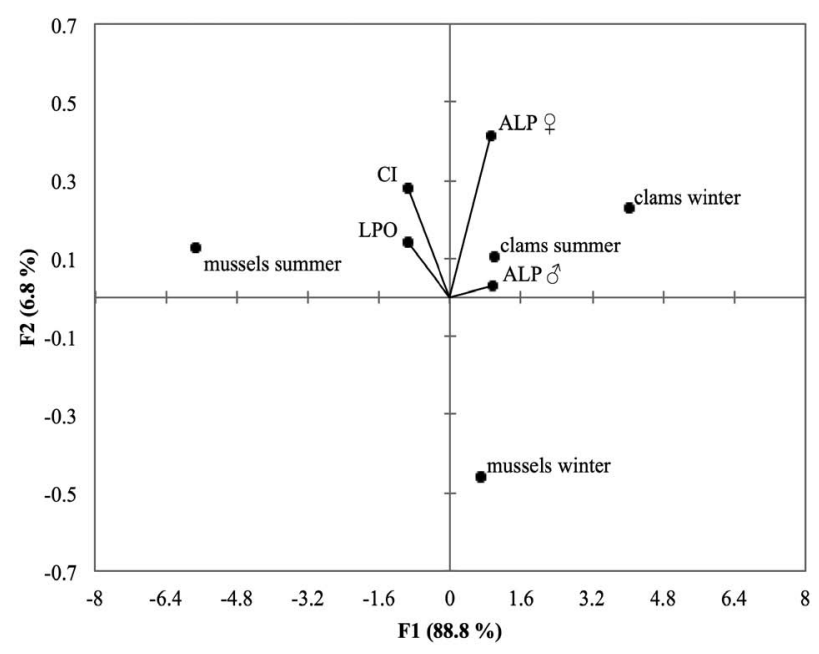

FIG. 5. - PCA of the ALP and LPO concentrations and Condition Index in mussels M. galloprovincialis and clams $R$. decussatus collected in both the summer and winter surveys. 


\section{DISCUSSION}

In order to understand the disruption induced by EDCs in the bivalve species M. galloprovincialis and $R$. decussatus, $\mathrm{Vg}$-like proteins were determined by the ALP method. Several authors have already reported the use of the ALP assay as an indirect assessment of estrogenic exposure and effects in bivalves, highlighting that higher ALP concentrations indicate the presence of environmental estrogens (Blaise et al. 1999, Gagné et al. 2001a, b, 2002, 2003, Quinn et al. 2004, Matozzo and Marin 2005, Porte et al. 2006, Matozzo et al. 2008, Gagnaire et al. 2009).

EDCs can induce vitellogenin synthesis in both genders; however, increases in Vg-like proteins in males and immature individuals are a better indication of environmental exposure by these compounds (Blaise et al. 1999, Marin and Matozzo 2004, Matozzo et al. 2008). In this study, neither mussels nor clams exhibited significant differences in the ALP concentrations between genders, conversely to the main idea that vitellogenin is produced specifically in females, as shown for vitellogenin protein and gene expression in other bivalves (Osada et al. 2004). Seasonal studies using different bivalve molluscs have shown that ALP levels follow the same trend as the gametogenic cycle in females, with mature individuals having naturally higher ALP concentrations. Only in the resting stages of gonadal development would females have ALP levels similar to males (Blaise et al. 1999, 2002, Matozzo and Marin 2005, Porte et al. 2006). In the present work, none of the females of either species were in gonadal stages that could explain the similarity of values between sexes. Female mussels were in post-spawning stages in both seasons and female clams were still spawning (in the summer). This situation suggests the influence of EDCs, which could induce vitellogenin synthesis and lead to higher ALP values in males. This was also verified in other studies with $M$. galloprovincialis (Ricciardi et al. 2008) and other bivalve species like Dreissena polymorpha (Quinn et al. 2004) and Tapes philippinarum (Matozzo and Marin 2005), which showed no differences in Vg-like protein levels between genders after exposure to contaminated environments (municipal effluents and nonylphenol).

When the ALP concentrations determined in $M$. galloprovincialis in the two sampling seasons are compared, females showed similar values while males showed higher levels (1.7-fold) in the winter. This is more evidence of the presence of EDCs in the environment. In winter, a higher availability of xenoestrogens may be related to an increased volume of discharges associated with periods of heavy rainfall as well as agricultural and land runoff, which, together with stronger hydrodynamic conditions, may promote an intense remobilization of contaminants from the sediment (Bebianno 1995, Bebianno and Serafim 2003). In $R$. decussatus, the maximum ALP concentrations were also detected in winter but in immature individu- als. This result supports the evidence that clams are exposed to EDC in this season, as for mussels, since immature clams should show basal levels of ALP (Matozzo and Marin 2007), i.e., lower concentrations than those found for females and males in summer. In previous studies, sexually undifferentiated bivalves (Elliptio complanata and T. philippinarum) have also been shown to respond to estrogenic compounds such as nonylphenol and estradiol (Gagné et al. 2001a, 2007, Matozzo and Marin 2005, 2008).

Mussels and clams exhibited the same pattern for the ALP concentrations, with no differences between genders and higher levels in the winter. Both species showed a coherent response to EDC exposure, mainly in winter. $R$. decussatus showed higher ALP values than $M$. galloprovincialis, possibly associated with a stronger responsiveness to EDCs or due to the influence of the reproductive cycle. In summer, clams were ripe and spawning, hence the higher ALP concentrations found. The different lifestyles and feeding habits of these two species can also provide an insight into the differences observed: clams are suspension feeders that live inside the sediment, where remobilization of contaminants can be high, while mussels are filter-feeders that feed from the surrounding water. Moreover, higher $\mathrm{Vg}$ concentrations may be a specific characteristic of $R$. decussatus.

Several species of bivalve molluscs have shown altered Vg levels after exposure to contaminated environments. Nevertheless, to our knowledge, this is the first study to report ALP concentrations in the gonads of $M$. galloprovincialis and $R$. decussatus. Other studies have determined ALP values in haemolymph (Pampanin et $a l .2005$ ) and the digestive gland (Ricciardi et al. 2008) of the same mussel species exposed to different EDCs, and have reported a similar range of variation in field and laboratory experiments (Table 3 ). In other mussel species, M. edulis showed the same range of ALP concentrations in males but higher in females. The two freshwater mussels Dreissena polymorpha and Elliptio complanata showed distinct patterns. While the former showed lower values the latter had higher ALP values (Table 3). As for clams, a wide range of ALP levels was determined in species like Tapes philippinarum and Mya arenaria, with males exhibiting a similar range of variation when exposed to contaminants in the field and the laboratory (Table 3). Molluscs are a very diverse group with great inter-specific variability, including anatomical, physiological and metabolic traits, which may lead to unique susceptibilities to EDCs (Ketata et al. 2008).

The contaminants present in the aquatic environment can lead to an impairment of the organism's antioxidant systems, causing overproduction of ROS and rendering them more sensitive to oxidative stress. Lipid peroxidation, which is considered as a damage biomarker, may then occur (Bebianno et al. 2004, Viarengo et al. 2007). LPO was determined in the gills of the bivalves since it is the primary site of contaminant 
TABLE 3. - ALP concentrations ( $\mu \mathrm{g} \mathrm{PO}_{4} \mathrm{mg}^{-1}$ Prot) determined in different mussel and clam species after exposure to contaminated environments, including the present study.

\begin{tabular}{|c|c|c|c|}
\hline Species & $\operatorname{ALP}\left(\mu \mathrm{g} \mathrm{PO}_{4} \mathrm{mg}^{-1}\right.$ Prot $)$ & Exposure/Site & Author \\
\hline Mytilus galloprovincialis (gonads) & 우 36.7-48.7; đ $36.3-60.6$ & Field study in the Ria Formosa Lagoon & Present study \\
\hline $\begin{array}{l}\text { Mytilus galloprovincialis } \\
\text { (haemolymph) }\end{array}$ & 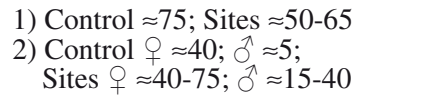 & $\begin{array}{l}\text { Sites under anthropogenic influence in Italy } \\
\text { 1) February } \\
\text { 2) April }\end{array}$ & Pampanin et al. 2005 \\
\hline $\begin{array}{l}\text { Mytilus galloprovincialis } \\
\text { (digestive gland) }\end{array}$ & 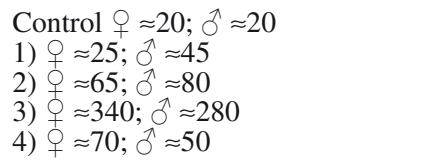 & $\begin{array}{l}\text { Exposure to Nonylphenol } \\
\text { 1) } 25 \mu \mathrm{g} \mathrm{L}^{-1} \\
\text { 2) } 50 \mu \mathrm{g} \mathrm{L}^{-1} \\
\text { 3) } 100 \mu \mathrm{g} \mathrm{L}^{-1} \\
\text { 4) } 200 \mu \mathrm{g} \mathrm{L}^{-1}\end{array}$ & Ricciardi et al. 2008 \\
\hline Mytilus edulis (gonads) & $\begin{array}{l}\text { Control } q \approx 500-200 ; \precsim \approx 35-50 \\
\text { NSO } q \approx 100 ; 0 \approx 35 \\
\text { MIX }+\approx 275 ; \hat{0} \approx 65 \\
\text { BPA }+\approx 500 ; 0 \approx 55\end{array}$ & $\begin{array}{l}\text { Laboratory exposure to NSO e MIX (NSO, } \\
\text { alkylphenol and PAHs) and BPA }\end{array}$ & $\begin{array}{l}\text { Ortiz-Zarragoitia and } \\
\text { Cajaraville } 2005\end{array}$ \\
\hline Mytilus edulis (gonads) & 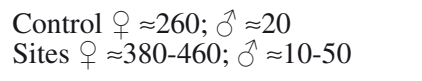 & $\begin{array}{l}\text { Exposure to a copper gradient near a mine } \\
\text { in Norway }\end{array}$ & Zorita et al. 2006 \\
\hline Dreissena polymorpha (gonads) & $\approx 0.9-1.3$ & $\begin{array}{l}\text { Exposed to surface waters upstream and } \\
\text { downstream of a municipal effluent outfall }\end{array}$ & Gagné et al. 2002 \\
\hline Dreissena polymorpha (gonads) & 우 $\approx 6-10 ; \widehat{\partial} \approx 5.5-8.5$ & Exposed to nonylphenol & Quinn et al. 2004 \\
\hline Elliptio complanata (gonads) & $q$ and $\widehat{\partial} \approx 110-225$ & Exposed to aeration lagoons & Gagné et al 2007 \\
\hline Ruditapes decussatus (gonads) & 우 65.7 ; ô 55.2; Immature 78.4 & Field study in the Ria Formosa Lagoon & Present study \\
\hline $\begin{array}{l}\text { Tapes philippinarum } \\
\text { (haemolymph) }\end{array}$ & $\begin{array}{l}\text { Immature control } \approx 15 ; \\
\text { exposed } \approx 11-60 \\
\text { control } q \approx 75-100 ; \hat{d} \approx 35 \\
\text { exposed } q \approx 20-275 ; \hat{\delta} \approx 15-140\end{array}$ & Exposed to estradiol & $\begin{array}{l}\text { Matozzo and Marin } \\
2008\end{array}$ \\
\hline $\begin{array}{l}\text { Tapes philippinarum } \\
\text { (digestive gland) }\end{array}$ & $\begin{array}{l}\text { Immature control } \approx 25-40 ; \\
\text { exposed } \approx 25-75 \\
\text { control } q \approx 10-25 ; \hat{\delta} \approx 12-18 \\
\text { exposed } q \approx 10-25 ; \hat{\delta} \approx 8-28\end{array}$ & Exposed to estradiol & $\begin{array}{l}\text { Matozzo and Marin } \\
2008\end{array}$ \\
\hline $\begin{array}{l}\text { Tapes philippinarum } \\
\text { (haemolymph) }\end{array}$ & $\begin{array}{l}\text { control } q \approx 260 ; \hat{O} \approx 175 \\
\text { exposed } q \approx 220-350 ; \hat{O} \approx 200-420\end{array}$ & Exposed to nonylphenol & $\begin{array}{l}\text { Matozzo and Marin } \\
2005\end{array}$ \\
\hline $\begin{array}{l}\text { Tapes philippinarum } \\
\text { (digestive gland) }\end{array}$ & $\begin{array}{l}\text { control } q \approx 650 ; \hat{\partial} \approx 15 \\
\text { exposed } q \approx 600-650 ; \hat{\sigma} \approx 20-65\end{array}$ & Exposed to nonyphenol & $\begin{array}{l}\text { Matozzo and Marin } \\
2005\end{array}$ \\
\hline Mya arenaria (haemolymph) & $q$ and $\hat{\delta} \approx 7.8-292$ & $\begin{array}{l}\text { Sites under different gradients and sources } \\
\text { of contamination in Canada }\end{array}$ & Blaise et al. 2002 \\
\hline Mya arenaria (haemolymph) & $q$ and $\widehat{\partial} \approx 10-290$ & $\begin{array}{l}\text { Sites under different gradients and sources } \\
\text { of contamination in Canada }\end{array}$ & Blaise et al. 1999 \\
\hline Mya arenaria (gonads) & $q \approx 3.2-5.5$ & Females injected with estradiol and nonylphenol & Gagné et al. 2002 \\
\hline
\end{tabular}

uptake in the aqueous phase and reflects short term exposure (Bebianno and Serafim 2003, Bebianno et al. 2004). In mussels, LPO values were higher in summer, reflecting an increase in environmental stress. This may be the result of enhanced contaminant inputs due to a rise in the anthropogenic influence associated with tourism pressure in this season, along with higher temperatures and light radiance in the water column in the Ria Formosa Lagoon (Bebianno and Serafim 2003, Cravo et al. 2009). Abiotic factors can also strengthen the responses of several biomarkers due to their synergistic effect with contaminants as, for example, increased toxicity of some metals or specia- tion alterations (Bebianno and Serafim 2003, Cravo et al. 2009). Higher temperatures can boost the filtration rate of $M$. galloprovincialis and therefore more bioavailable contaminants can be accumulated (Bebianno and Serafim 2003). On the other hand, clams showed higher LPO concentrations in winter, although the difference between seasons was small. It has been shown that a reduction in the antioxidant defence system occurs in winter that could be directly responsible for an enhanced susceptibility of clams to oxidative stress, and therefore they showed higher LPO levels. Seasonal variations can also be associated with fluctuations in the metabolic status of animals that are related to other 
factors, such as gonad ripening and food availability (Hamza-Chaffai et al. 2003) as well as higher contaminant availability due to intense remobilization of the sediments during periods of higher hydrodynamism.

Mussels show a more evident seasonal effect in the LPO concentrations, indicating that these filter feeding organisms that live in suspension are more influenced by seasonal variations in the environmental factors that vary to a greater degree in the water column, such as increases in temperature, intensity of light radiance and food availability, compared to sediment-associated clams that are not so dependent on environmental variations in the water column. These seasonal variations are directly connected to an increase of the prooxidant challenge, which can compromise the antioxidant efficiency of organisms and lead to an increase in oxidative damage like LPO (Bocchetti et al. 2008). Lipid peroxidation in M. galloprovincialis from the Ria Formosa Lagoon followed the same seasonal trend to that found for the same species at the same site in the summer of $2005\left(18.6 \mu \mathrm{mol} \mathrm{g}{ }^{-1}\right.$ Prot $)$ and winter of 2006 (6.4 umol g ${ }^{-1}$ Prot), although with lower levels (Pereira, unpublished data). This may be a reflection either of a decrease in contaminants inducing LPO or an adaptive antioxidant response over time to counteract ROS generation leading to a lower lipid peroxidation. M. galloprovincialis from low to high impacted sites on the NW coast of Portugal (Lima et al. 2007) and Balearic Islands in Spain (Box et al. 2007) showed slightly higher LPO values (9-12 and 7.7-12.1 $\mu \mathrm{mol}$ $\mathrm{g}^{-1}$ Prot, respectively) compared to the ones obtained in this study, which are indicative of the low or moderate levels of contamination found in mussels from the Ria Formosa Lagoon (Cravo et al. 2009). As for clams, LPO values were similar to those found for the same species in the same lagoon in previous years (0.4-0.6 $\mu \mathrm{mol} \mathrm{g}{ }^{-1}$ Prot, Géret and Bebianno 2004; Bebianno and Barreira, 2009) and relatively lower than in Thau lagoon in France $\left(0.643 \mu \mathrm{mol} \mathrm{g}{ }^{-1}\right.$ Prot, Bebianno et al. 2004).

Many endocrine-related effects can be significantly associated with oxidative metabolisms and stress endpoints, which are associated with tissue damage (Gagné et al. 2007). In the present study, Vg-like proteins and LPO patterns were the opposite in mussels but similar in clams. No correlations were found between the two biomarker responses and nor were they associated in the PCA analysis (Fig. 5), which could mean that some endocrine disrupting compounds may not have oxidative damage potential, as stated previously when considering the sources of contamination. However, there was a clear separation between species, with clams related to higher ALP concentrations and mussels to LPO and CI values. The physiological condition can also be important since it represents the nutritional state of the organism (Moschino and Marin 2006, Matozzo and Marin 2007). The energy required to support vitellogenesis by endogenous or exogenous inputs of estrogenic contami- nants represents a major expenditure for bivalves, thus contributing to the increase in energy demands, lowering their condition indexes (Gagné et al. 2003, Gagnaire et al. 2009). Hence, the observed higher ALP and/or LPO coupled with lower CI could be indicative of exposure to contaminants, which is supported by the negative correlation found between ALP concentrations in males and the CI. The presence of EDCs was probably able to induce the expression of $\mathrm{Vg}$-like proteins in males due to their susceptibility related to a lower physiological status. This association may have not been clear for females since Vg-like proteins are normally expressed during gametogenesis and their induction by estrogenic chemicals could be masked. Although no other significant correlation was found between ALP, LPO and CI in either species, a clear tendency towards higher ALP concentrations coupled with a lower condition index was observed, especially for clams, as reflected in the PCA analysis (Fig. 5).

The Ria Formosa Lagoon is influenced by several point or diffuse sources of contaminants, namely domestic and/or industrial effluents, port facilities and agricultural runoffs (Bebianno 1995, Cravo et al. 2009, Maria et al. 2009). Complex mixtures that include metals, polycyclic aromatic hydrocarbons (PAHs), organotin compounds (e.g. manly TBT) and polychlorinated byphenyls (PCBs) have been detected in $M$. galloprovincialis and $R$. decussatus as well as in water and sediments collected in the Lagoon (Table 1). The results of endocrine disruption and oxidative stress in this study reflect the results obtained in other studies on the presence of different contaminants in Ria Formosa waters, as well as the complex interactions between them (Coelho et al. 2002, Bebianno and Serafim 2003, Barreira et al. 2005, Díez et al. 2005, Barreira et al. 2007, Bebianno and Barreira 2009, Cravo et al. 2009). The two determined biomarkers are not specific to a particular group of contaminants but could represent an integrated response to the impact of multiple toxic and/or environmental factors (Lafontaine et al. 2000). At the specific sampling site near Olhão city, the compounds mentioned before are known to act as endocrine disruptors (Matozzo et al. 2008) and inducers of oxidative stress (Viarengo et al. 2007) in invertebrates, and can be related to a fishing and boat traffic environment and vicinity of a major urban area (Barreira et al. 2007, Maria et al. 2009). Other authors have established a relationship between the contaminants present in this environment and the consequent effects in the sentinel species used in the research, such as elevated LPO levels (Bebianno and Barreira 2009, Cravo et al. 2009). However, in terms of endocrine disruptors in $M$. galloprovincialis and $R$. decussatus, this represents the first attempt to use $\mathrm{Vg}$-like proteins as a biomarker for estrogenic assessment in the Ria Formosa Lagoon. For this ecosystem, only exposure alterations like intersex (presence of oocytes in the testis of males) in Scrobicularia plana clams (Gomes et al. 2009) and imposex (superimposition of male characters onto females) in 
the prosobranch Ocenebra erinacia (Coelho 2005) have been described.

Both species appear to be under the influence of exposure to EDCs (which could induce vitellogenin synthesis) in the Ria Formosa Lagoon mainly in the winter. M. galloprovincialis and $R$. decussatus responded to the effects of complex mixtures present in the environment, validating their use as sentinel species in environmental quality assessment.

\section{REFERENCES}

Barreira L.A., Bebianno M.J., Mudge S.M. 2005. Relationship between PCBs in suspended and settled sediments from a coastal lagoon. Cienc. Mar. 31(1B): 179-195.

Barreira L.A., Mudge S.M., Bebianno M.J. 2007. Polycyclic aromatic hydrocarbons in clams Ruditapes decussatus (Linnaeus, 1758). J. Environ. Monit. 9: 187-198.

Bebianno M.J. 1995. Effects of pollutants in the Ria Formosa Lagoon, Portugal. Sci. Total Environ. 171: 107-115.

Bebianno M.J., Serafim A. 2003. Variation of metal and metallothionein concentrations in a natural population of Ruditapes decussatus. Arch. Environ. Contam. Toxicol. 44: 53-66.

Bebianno M.J., Barreira L.A. 2009. Polycyclic aromatic hydrocarbons concentrations and biomarker responses in the clam Ruditapes decussatus transplanted in the Ria Formosa lagoon. Ecotoxicol. Environ. Saf. 72: 1849-1860.

Bebianno M.J., Géret F., Hoarau P., Serafim M.A., Coelho M.R., Gnassia-Barelli M., Roméo M. 2004. Biomarkers in Ruditapes decussatus: a potential bioindicator species. Biomarkers 9 (45): 305-330.

Blaise C., Gagné F., Pellerin J., Hansen P.D. 1999. Determination of vitellogenin-like properties in Mya arenaria hemolymph (Saguenay Fjord, Canada): a potential biomarker for endocrine disruption. Environ. Toxicol. 14: 455-465.

Blaise C., Gagné F., Pellerin J., Hansen P.-D., Trottier S. 2002. Molluscan Shellfish Biomarker Study of the Quebec, Canada, Saguenay Fjord with the Soft-Shell Clam, Mya arenaria. Environ. Toxicol. 17: 170-186.

Bocchetti R., Fattorini D., Pisanelli B., Macchia S., Oliviero L., Pilato F., Pellegrini D., Regoli F. 2008. Contaminant accumulation and biomarker responses in caged mussels, Mytilus galloprovincialis, to evaluate bioavailability and toxicological effects of remobilized chemicals during dredging and disposal operations in harbour areas. Aquat. Toxicol. 89: 257-266.

Box A., Sureda A., Galgani F., Pons A., Deudero S. 2007. Assessment of environmental pollution at Balearic Islands applying oxidative stress biomarkers in the mussel Mytilus galloprovincialis. Comp. Biochem. Physiol. C 146: 531-539.

Bradford M. 1976. A Rapid and Sensitive Method for the Quantitation of Microgram Quantities of Protein Utilizing the Principle of Protein-Dye Binding. Anal. Biochem. 72: 248-254.

Coelho M.R.T.C.N. 2005. Bioaccumulation and effects of TBT on molluscs from southern Portugal. Ph.D. thesis, Univ. Algarve.

Coelho M.R., Bebianno M.J., Langston W.J. 2002. Organotin levels in the Ria Formosa lagoon, Portugal. Appl. Organometal. Chem. 16: 384-390.

Cossu C., Doyotte A., Babut A., Exinger A., Vasseur P. 2000. Antioxidant Biomarkers in Freshwater Bivalves, Unio tumidus, in Response to Different Contamination Profiles of Aquatic Sediments. Ecotoxicol. Environ. Saf. 45: 106-121.

Cravo A., Lopes B., Serafim A., Company R., Barreira L., Gomes T., Bebianno M.J. 2009. A multibiomarker approach in Mytilus galloprovincialis to assess environmental quality. J. Environ. Monit. 11: 1673-1686.

Díez S., Lacorte S., Vianna P., Barceló D., Bayona J. M. 2005. Survey of organotin compounds in rivers and coastal environments in Portugal 1999-2000. Environ. Pollut. 136: 525-536.

Erdelmeier I., Gerard-Monnier D., Yadan J.C., Acudiere J. 1998. Reactions of N-methyl-2-phenylindole with malondialdehyde and 4-hydroxyalkenals. Mechanistic aspects of the colorimetric assay of lipid peroxidation. Chem. Res. Toxicol. 11: 1184-1194.

Gagnaire B., Gagné F., André C., Blaise C., Abbaci K., Budzinski
H., Dévier M.-H., Garric J. 2009. Development of biomarkers of stress related to endocrine disruption in gastropods: Alkalilabile phosphates, protein-bound lipids and vitellogenin-like proteins. Aquat. Toxicol. 92: 155-167.

Gagné F., Blaise C. 1998. Estrogenic properties of municipal and industrial wastewaters evaluated with a rapid and sensitive chemoluminescent in situ hybridization assay (CISH) in rainbow trout hepatocytes. Aquat. Toxicol. 44: 83-91.

Gagné F., Blaise C., Salazar M., Salazar S., Hansen P.D. 2001a. Evaluation of estrogenic effects of municipal effluents to the freshwater mussel Elliptio complanata. Comp. Biochem. Physiol. $C$ 128: 213-225.

Gagné F., Blaise C., Lachance B., Sunahara G.I., Sabik H. 2001b. Evidence of coprostanol estrogenicity to the freshwater mussel Elliptio complanata. Environ. Pollut. 115: 97-106.

Gagné F., Blaise C., Pellerin J., Gauthier-Clerc S. 2002. Alteration of the biochemical properties of female gonads and vitellins in the clam Mya arenaria at contaminated sites in the Saguenay Fjord. Mar. Environ. Res. 53: 295-310.

Gagné F., Blaise C., Pellerin J., Pelletier E., Douville M., GauthierClerc S., Viglino L. 2003. Sex alteration in soft-shell clams (Mya arenaria) in an intertidal zone of the Saint Lawrence River (Quebec, Canada). Comp. Biochem. Physiol. C 134: 189-198.

Gagné F., Blaise C., André C., Gagnon C., Salazar M. 2007. Neuroendocrine disruption and health effects in Elliptio complanata mussels exposed to aeration lagoons for wastewater treatment. Chemosphere 68: 731-743.

Géret F., Bebianno M.J. 2004. Does zinc produce reactive oxygen species in Ruditapes decussatus? Ecotoxicol. Environ. Saf. 57: 399-409.

Gomes T., Gonzalez-Rey M., Bebianno M.J. 2009. Incidence of intersex in male clams Scrobicularia plana in the Guadiana Estuary (Portugal). Ecotoxicol. 18(8): 1104-1109.

Hamza-Chaffai A., Pellerin J., Amiard J.C. 2003. Health assessment of a marine bivalve Ruditapes decussatus from the Gulf of Gabès (Tunisia). Environ. Int. 28: 609-617.

Ketata I., Denier X., Hamza-Chaffai A., Minier C. 2008. Endocrinerelated reproductive effects in molluscs. Comp. Biochem. Physiol. C 147: 261-270.

Lafontaine Y., Gagné F., Blaise C., Costan G., Gagnon P., Chan H.M. 2000. Biomarkers in zebra mussels (Dreissena polymorpha) for the assessment and monitoring of water quality of the St Lawrence River (Canada). Aquat. Toxicol. 50: 51-71.

Lima I., Moreira S.M., Osten J.R.-V., Soares A.M.V.M., Guilhermino L. 2007. Biochemical responses of the marine mussel Mytilus galloprovincialis to petrochemical environmental contamination along the North-western coast of Portugal. Chemosphere 66: $1230-1242$.

Lowry O.H., Rosenbrough N.J., Farr A.L., Randall R.J. 1951. Protein measurement with Folin phenol reagent. J. Biol. Chem. 193: 265-275.

Maria V.L., Santos M.A., Bebianno M.J. 2009. Contaminant effects in shore crabs (Carcinus maenas) from Ria Formosa Lagoon. Comp. Biochem. Physiol. C 150: 196-208.

Marin M.G., Matozzo V. 2004. Vitellogenin induction as a biomarker of exposure to estrogenic compounds in aquatic environments. Mar. Pollut. Bull. 48: 835-839.

Matozzo V., Marin M.G. 2005. Can 4-nonylphenol induce vitellogenin-like proteins in the clam Tapes philippinarum? Environ. Res. 97: 43-49.

Matozzo V., Marin M.G. 2007. First evidence of altered vitellogenin-like protein levels in clam Tapes philippinarum and in cockle Cerastoderma glaucum from the Lagoon of Venice. Mar. Pollut. Bull. 55: 494-504.

Matozzo V., Marin M.G. 2008. Can 17ß-estradiol induce vitellogenin-like proteins in the clam Tapes philippinarum? Environ. Toxicol. Pharmacol. 26: 38-44.

Matozzo V., Gagné F., Marin M. G., Ricciardi F., Blaise C. 2008. Vitellogenin as a biomarker of exposure to estrogenic compounds in aquatic invertebrates: A review. Environ. Int. 34: 531-545.

Moschino V., Marin M.G. 2006. Seasonal changes in physiological responses and evaluation of "well-being" in the Venus clam Chamelea gallina from the Northern Adriatic Sea. Comp. Biochem. Physiol. A 145: 433-440.

Ortiz-Zarragoitia M., Cajaraville M.P. 2005. Biomarkers of Exposure and Reproduction-Related Effects in Mussels Exposed to Endocrine Disruptors. Arch. Environ. Contam. Toxicol. 49:1-10. 
Osada M., Harata M., Kishida M., Kijima A. 2004. Molecular cloning and expression analysis of vitellogenin in scallop, Patinopecten yessoensis (Bivalvia, Mollusca). Mol. Reprod. Dev. 67: 273-281.

Pampanin D.M., Marangon I., Volpato E., Campesan G., Nasci C. 2005. Stress biomarkers and alkali-labile phosphate level in mussels (Mytilus galloprovincialis) collected in the urban area of Venice (Venice Lagoon, Italy). Environ. Pollut. 136:103-107.

Porte C., Janer G., Lorusso L. C., Ortiz-Zarragoitia M., Cajaraville M.P., Fosse M.C., Canesi L. 2006. Endocrine disruptors in marine organisms: Approaches and perspectives. Comp. Biochem. Physiol. C 143: 303-315.

Quinn B., Gagné F., Costello M., McKenzie C., Wilson J., Mothersill C. 2004. The endocrine disrupting effect of municipal effluent on the zebra mussel (Dreissena polymorpha). Aquat. Toxicol. 66: 279-292.

Ribeiro J., Monteiro C.C., Monteiro P., Bentes L., Coelho R., Goncalves J.M.S., Lino P.G., Erzini K. 2008. Long-term changes in fish communities of the Ria Formosa coastal lagoon (southern Portugal) based on two studies made 20 years apart. Estuar. Coast. Shelf. Sci. 76: 57-68.
Ricciardi F., Matozzo V., Marin M.G. 2008. Effects of 4-nonylphenol exposure in mussels (Mytilus galloprovincialis) and crabs (Carcinus aestuarii) with particular emphasis on vitellogenin induction. Mar. Pollut. Bull. 57: 365-372.

Stanton M.G. 1968. Colorimetric determination of inorganic phosphate in the presence of biological material and adenosine triphosphate. Anal. Biochem. 22: 27-34.

Viarengo A., Lowe D., Bolognesi C., Fabbri E., Koehler A. 2007. The use of biomarkers in biomonitoring: A 2-tier approach assessing the level of pollutant-induced stress syndrome in sentinel organisms. Comp. Biochem. Physiol.C 146: 281-300.

Villalba A. 1995. Gametogenic cycle of cultured mussel, Mytilus galloprovincialis, in the bays of Galicia (N.W. Spain). Aquaculture 130: 269-277.

Zorita I., Ortiz-Zarragoitia M., Soto M., Cajaraville M.P. 2006. Biomarkers in mussels from a copper site gradient (Visnes, Norway): An integrated biochemical, histochemical and histological study. Aquat. Toxicol. 78S: S109-S116.

Received April 17, 2011. Accepted October 3, 2011.

Published online January 7, 2013. 